\title{
VERTICAL FORCES ACTING ON CULTIVATOR TINES IN THE ASPECT OF SHEARING SPEED AND FLEXIBILITY OF TINES
}

\author{
Krzysztof Lejman $^{\mathrm{a}^{*}}$, Zygmunt Owsiak ${ }^{\mathrm{a}}$, Krzysztof Pieczarka ${ }^{\mathrm{a}}$, Tomasz Sekutowski ${ }^{\mathrm{b}}$ \\ ${ }^{a}$ Institute of Agricultural Engineering, Wroclaw University of Environmental and Life Sciences \\ ${ }^{\mathrm{b}}$ Institute of Soil Science and Cultivation - in Puławy \\ "Corresponding author: e-mail: krzysztof.lejman@upwr.edu.pl
}

\begin{tabular}{|c|c|}
\hline ARTICLE INFO & ABSTRACT \\
\hline $\begin{array}{l}\text { Article history: } \\
\text { Received: April } 2018 \\
\text { Received in the revised form: } \\
\text { May } 2018 \\
\text { Accepted: June } 2018 \\
\end{array}$ & \multirow{2}{*}{$\begin{array}{l}\text { The objective of the paper was to determine the impact of the shearing } \\
\text { speed and cultivator tines flexibility on the vertical forces value. The } \\
\text { study was carried out in field conditions in sandy clay soil and the } \\
\text { average moisture of } 11.2 \% \text {. The vertical forces acting on four "s" tines } \\
\text { with flexibility of } 0.0061 ; 0.0711 ; 0.0953 \text { and } 0.1406 \mathrm{~m} \cdot \mathrm{kN}^{-1} \text { were } \\
\text { measured. Tines were ended with a cultivator point with the curvature } \\
\text { radius of } 0.17 \mathrm{~m} \text {. Measurements were made for four shearing speeds } \\
\left(1.0 ; 1.7 ; 2.4 \text { and } 3.0 \mathrm{~m} \cdot \mathrm{s}^{-1}\right) \text { and the shearing depth of } 11 \mathrm{~cm} \text {. A stand } \\
\text { for measurement of forces acting on soil shearing farm tools in field } \\
\text { conditions was used. It was concluded that the shearing speed caused } \\
\text { a linear increase of the vertical force but the growth gradient does not } \\
\text { depend on the tines flexibility. It was also concluded that the increase } \\
\text { in flexibility causes an initial increase and then decrease of the vertical } \\
\text { force, which was described with the second degree parabola equation. } \\
\text { Flexibilities, at which extremes of courses occur, grow along with the } \\
\text { reduction of the shearing speed. }\end{array}$} \\
\hline $\begin{array}{l}\text { Key words: } \\
\text { soil, } \\
\text { cultivator, } \\
\text { flexible tine, } \\
\text { vertical forces, } \\
\text { shearing speed }\end{array}$ & \\
\hline
\end{tabular}

\section{Introduction}

Soil shearing elements in the form of flexible tines are widely used at various stages of field plant production related to soil cultivation. They are used in multi-action cultivation units and tools for interrow cultivation. In many cases, particularly in the Polish conditions, they are still used as working elements of independent spring-tine cultivators. The growth of interest in flexible tines mainly results from the observed trend of partial or total resignation from the most energy consuming treatment, namely ploughing. According to many authors, simplification of cultivation treatments causes reduction of energy consumption, reduces soil degradation and favourably influences the yields (Chen et al., 2005; Talarczyk and Zbytek, 2006; Rouw et al., 2010). The consequence of the discussed trend is intensification of the experimental research carried out for single shearing elements (Sahu and Raheman, 2006; Zhang and Chen, 2017; Manuwa, 2009) and whole tools (Przybył et al., 2009; Al-Janobi et al., 2002) and theoretical research (Ucgul et al., 2015; Al-Kheer et al., 2011; Wahed and Aboukarima, 2007), devoted to the influence of the cultivator tine on soil. 
K. Lejman, Z. Owsiak, K. Pieczarka, T. Sekutowski

However, it should be noticed that all theoretical models, mainly based on the application of neural networks and finite elements method (FEM) and discreet elements method (DEM) allow only for interpretation of phenomena which take place during soil shearing with tools that are not subject to elastic strains. Limited possibilities of using theoretical models for prediction of forces acting on the flexibly deforming model mainly result from variability of shearing elements and shearing unit geometry which take place during the tool operation in soil. This variability impedes also interpretation of the research outcomes obtained by means of experiments since it requires the inclusion of momentary values of the dynamically changing recorded signal and correlating it in time with variable parameters of shearing (Lisowski et al., 2016; Bernsten et al., 2006). Correlation of registered signals is possible only in case of measurements carried out for single shearing elements because at a given moment, particular shearing elements of the entire tool may work on various depths, which results in various horizontal shifts of cultivator points and their various rake angles.

The presented problems related to the analysis of forces acting on the flexible cultivator tines cause that authors focus mainly on the most important parameter, namely shearing resistance, which determines energy consumption of the treatment. Vertical forces which result from loading of shearing elements which are shifted to coping and supporting units indirectly influence energy consumption. Moreover, the vertical stability of a tool, its penetration ability and impact on the tractor linkage hitch suspension affect the value and the sense of those forces (Shmulevich et al., 2007; Davoudi et al., 2008; Askari et al., 2016). It causes that knowing the value of these forces is necessary as early as at the stage of tool design.

The objective of the research was to determine the impact of cultivator tines flexibility on the value of vertical forces acting on them, including the changes of the shearing speed on light soil.

\section{Methodology of research}

The forces that act on flexible cultivator tines were measured in the field conditions. Participation of soil fraction groups determined with Bouyoucos-Casagrande in Prószyński's modification was: gravel $-4 \%$, sand $-67 \%$, silt $-18 \%$ and clay $-11 \%$. According to classification of soil and mineral forms granulation (PTG 2008) it is sandy loam soil. The present condition of soil during the study was described with moisture $(11.2 \%)$, soil cone index $(600 \mathrm{kPa})$, volumetric density $\left(1470 \mathrm{~kg} \cdot \mathrm{m}^{-3}\right)$ and shearing resistance in the conditions of the border balance $(44 \mathrm{kPa})$. Standard deviations of measurements of particular parameters were respectively $0.5 \%, 70 \mathrm{kPa}, 30 \mathrm{~kg} \cdot \mathrm{m}^{-3}$ and $8 \mathrm{kPa}$. Moisture was determined with the oven-drying method. Compaction was measured with a dynamic cone with the surface area of the base of $3 \mathrm{~cm}^{2}$ and the vertical angle of $60^{\circ}$ at the speed of $3 \mathrm{~cm} \cdot \mathrm{s}^{-1}$. Soil samples for the measurement of density were collected with Kopecki tool and measuring cylinders with the volume of $100 \mathrm{~cm}^{3}$. Shearing resistance was determined with sonde 
Vertical forces acting...

Geonor VANE H-60. Each of the mentioned parameters was determined in 10 iterations. Maintaining stable conditions of the research at determination of the impact of the shearing speed and tines flexibility on the values of forces required soil uniformity which was obtained by means of deep scarification and then surface and in-depth compaction.

Forces acting on the flexible cultivator tine were measured with the stand, the image of which and schematic representation of the measuring stand were presented in figure 1 . The main element of the stand is a multi-axis force transducer (1) which enables a simultaneous measurement of the horizontal force $(\mathrm{Fx})$, vertical force $(\mathrm{Fy})$ and the force moment $(\mathrm{M})$. The moving cultivator tine (9) is preceded with the sensor wheel (7) with a tensometric system (8). Due to the use of a sensor wheel it is possible to register a real depth of the tool work. Voltage signals from the transducer are send to the data canvasser (6) consisting of a high-stability supplier (2), voltage measurement system (5), mass memory (3) and interface (4) that enables recording data in the computer. The vertical force and a momentary shearing depth was recorded with the frequency of $1000 \mathrm{~Hz}$ at the measurement error of respectively $5 \mathrm{~N}$ and $1 \mathrm{~cm}$.

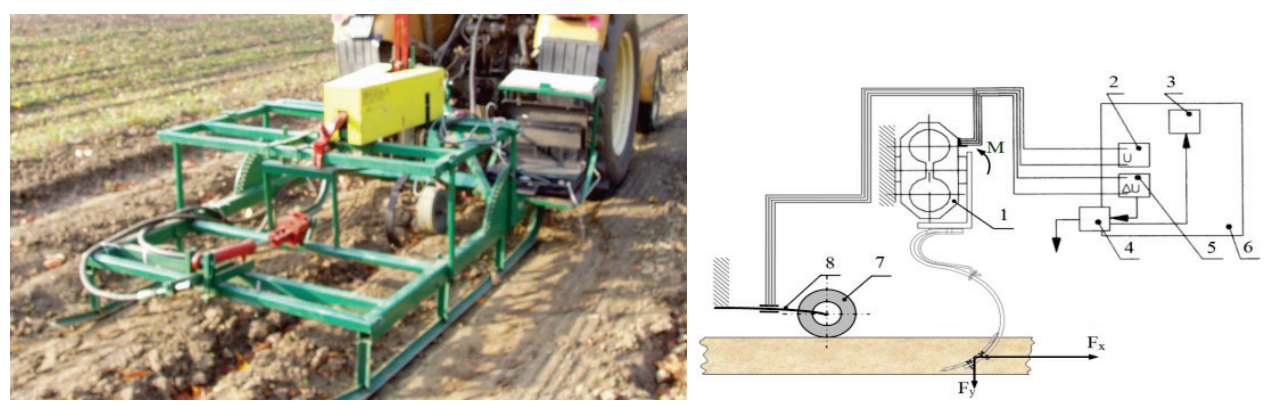

Figure 1. View of stand and schematic representation of its measuring system (description of symbols in the text)

The shearing speed and tine flexibility were independent variables. Four shearing speeds were used $-1.0 ; 1.7 ; 2.4$ and $3.0 \mathrm{~m} \cdot \mathrm{s}^{-1}$ and four tines with varied flexibilities $0.0061 ; 0.0711 ; 0.0953$ and $0.1406 \mathrm{~m} \cdot \mathrm{kN}^{-1}$. Horizontal shift of the cultivator point referred to the value of horizontal force load were assumed as the flexibility measure. This parameter was determined with the strength machine Instron 5566. Tines ended with a cultivator point with the width of $0.045 \mathrm{~m}$ and the curvature radius of $\mathrm{R}=0.17 \mathrm{~m}$ were presented in figure 2. A tine with the standard structure (2c) and modified tines ( $2 \mathrm{a}, 2 \mathrm{~b}$ and $2 \mathrm{~d}$ ) were used. The purpose of $2 a$ and $2 b$ tines modification was to reduce their flexibility which was obtained by the use of stiffening elements (1 and 2). The increase of the tine flexibility (2d) was obtained due to tine narrowing (3) at its particular length. As a result of changing loads during soil shearing with flexible tines, they become deformed, and as a result the cultivator point is shifted. Structural changes were carried out in a way that with analogous horizontal shifts of the cultivator point, its rake angle had the same value for all the investigated tines. 


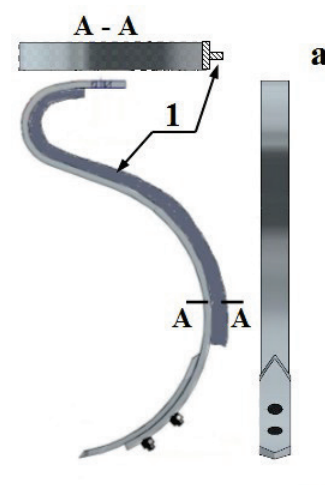

a

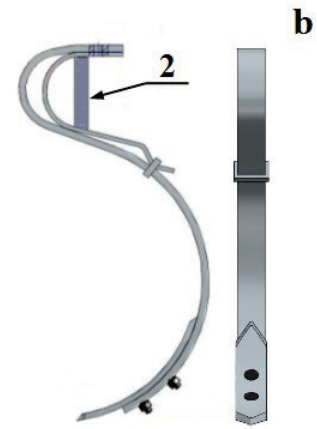

b

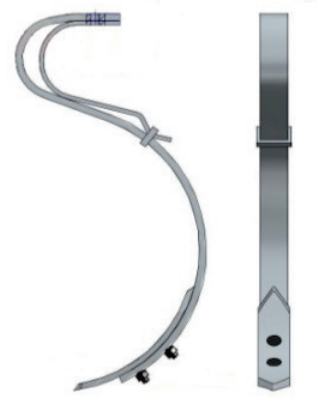

c

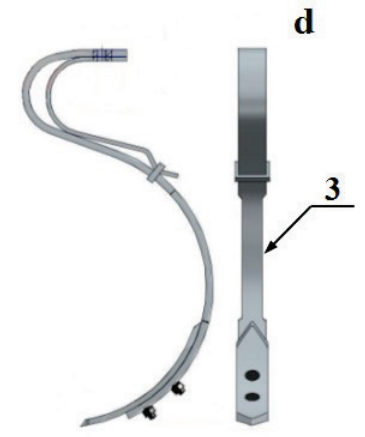

Figure 2. Flexible cultivator tines with various flexibilities: a $-0.0061 \mathrm{~m} \cdot \mathrm{kN}^{1}$; $b-0.0711 \mathrm{~m} \cdot k N^{-1} ; c-0.0953 \mathrm{~m} \cdot k N^{-1}$ and $d-0.1406 \mathrm{~m} \cdot \mathrm{kN} \mathrm{N}^{-1}$

During the research carried out in the field conditions, a high variability of the momentary working depth takes place which results from irregularity of the field surface area. Determination of the impact of the shearing speed and tines flexibility on the vertical forces value creates a need to include those forces, which were recorded, at the same shearing depth. It is necessary because according to many authors (Sánchez-Girón et al., 2005; AlJanobi et al., 2002; Berntsen et al., 2006) the shearing depth is the most important factor that decides on the values of those forces. Before studies were initiated, it has been assumed that the impact of variable parameters of the experiment will be determined for the shearing depth of $11 \mathrm{~cm}$. At such initially set depth, variability of its recorded values was within 8 to $13 \mathrm{~cm}$.

Simultaneous measurement of the force and real depth allowed inclusion during the analysis of only such fragments of the force course in time which were recorded at the shearing depth within $\pm 0.5 \mathrm{~cm}$ in comparison to the assumed one which is $11 \mathrm{~cm}$. The included range results from the error of the measurement of the momentary shearing depth, which was $1 \mathrm{~cm}$. The recorded signals from the depth sensor and force transducer required correlation which consisted in the shift in time of signals from those sensors. A detailed methodology of determination of the fragments of the force course and the manner of correlation of signals from the depth and force sensors were presented in the paper by Lejman et al., (2015). All measurements of forces were carried out in four independent iterations, but 
Vertical forces acting...

in each of iterations, the average value of the force was determined, which was recorded in the assumed range of the work depth variability. During the studies it was assumed that the vertical forces, namely with the downward sense are positive forces.

A statistical study of the obtained results was carried out based on the analysis of correlations and regression and the test for comparison of straight deviations coefficients.

\section{Research results}

The increase of the shearing speed within 1.0 to $3.0 \mathrm{~m} \cdot \mathrm{s}^{-1}$ causes a linear increase of the vertical force (fig. 3). Indeed it confirms the results published in the papers by Lisowski et al., (2016), Al-Janobi et al., (2002) and Al-Kheer et al., (2011), but authors of the last two papers concluded that this relation is statistically insignificant. No significance of the impact of speed in case of the quoted papers may result from the research which was performed in a considerably narrow ranges of speeds, which were $0.75-1.92 \mathrm{~m} \cdot \mathrm{s}^{-1}$ (Al.- Janobi et al., 2002) and $1.50-1.90 \mathrm{~m} \cdot \mathrm{s}^{-1}(\mathrm{Al}-$ Kheer et al., 2011).

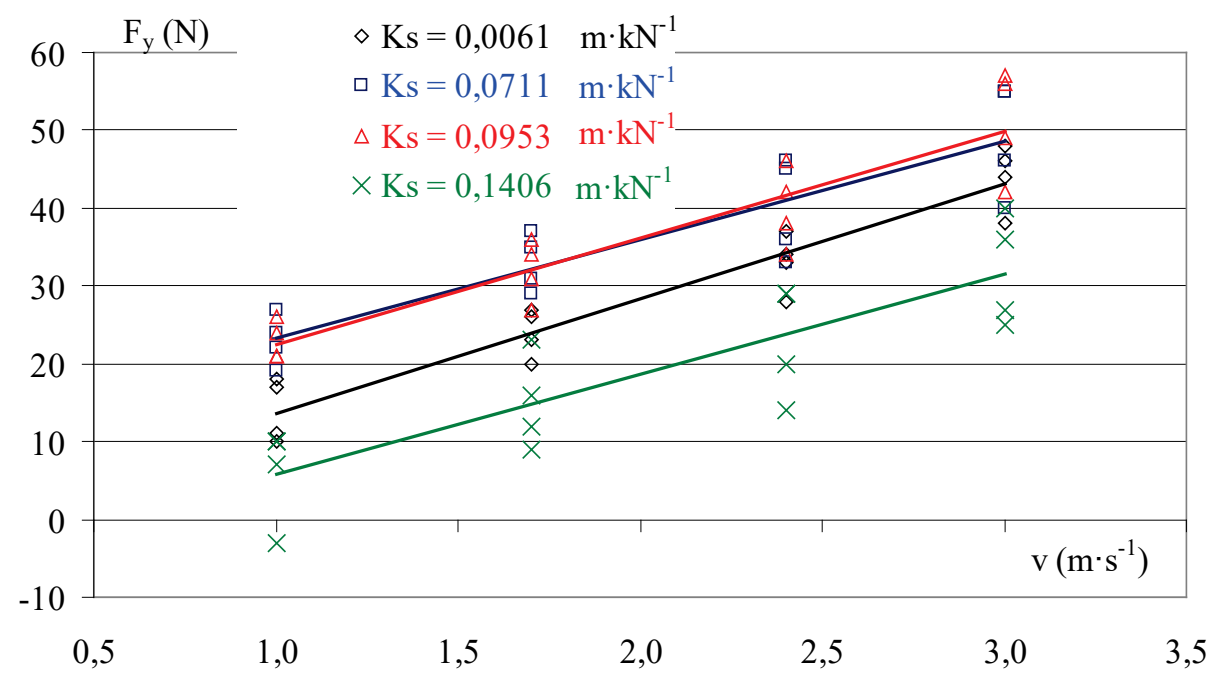

Figure 3. The impact of shearing speed (v) on the vertical force value $\left(F_{y}\right)$ at various flexibilities of tines $\left(K_{s}\right)$

The research results (figure 3) which were carried out in a wide scope of speeds (1.0-3.0 $\mathrm{m} \cdot \mathrm{s}^{-1}$ ), do not confirm the lack of correlation between the vertical force and the shearing speed. The obtained courses were described with the equation of the straight line which does not go through the beginning of the coordinate system, but the coefficients ( $a$ and $b$ ) of equations were presented in table 1 . The determination coefficients values obtained from the regression relations are within 0.7308 and 0.9121 and the correlation coefficients at 14 degrees of freedom are significant for the level of significance $\alpha=0.001$. The increase of the vertical force at the increase of the shearing speed may be explained with the increase 
of the vertical component force of inertia of the shifted soil. Analysis of the presented regression equations allows observation that values of slopes are similar (Table 1). Based on the above, a hypothesis was made that the tine flexibility does not significantly affect the value of the slope. In order to confirm this hypothesis, a test was carried out to compare coefficients of straight deviations. The calculated value of the test function (F) is 0.3245 while the table function value $\left(\mathrm{F}_{0,05 ; 3 ; 56}\right)$ is 2.78 . The hypothesis was confirmed since $\mathrm{F}<\mathrm{F}_{0,05 ; 3 ; 56}$. It means that the tine flexibility does not significantly affect the intensity of the vertical force increase at the shearing speed growth.

Table 1.

Coefficient ( $a$ and $b$ ) of the equation $F_{y}=a \cdot v+b$ and the statistical analysis result

\begin{tabular}{lccccc}
\hline \multirow{K}{*}{$\begin{array}{l}\mathrm{Ks} \\
\left(\mathrm{m} \cdot \mathrm{kN}^{-1}\right)\end{array}$} & $\mathrm{a}$ & $\mathrm{b}$ & $\mathrm{R}$ & $\mathrm{p}$ & $\mathrm{df}$ \\
\cline { 2 - 3 } 0.0061 & 14.7 & -1.1 & 0.956 & $<0,001$ & 14 \\
\hline 0.0711 & 12.7 & 10.6 & 0.892 & $<0,001$ & 14 \\
\hline 0.0953 & 13.7 & 8.8 & 0.920 & $<0,001$ & 14 \\
\hline 0.1406 & 12.8 & -6.9 & 0.855 & $<0,001$ & 14 \\
\hline
\end{tabular}

The increase of the tine flexibility initially causes the increase and then decrease of the vertical force value which was presented in figure 4 . Changes of the vertical force value in relation to the tine flexibility were described with the parabola equation. Values of coefficients $(\mathrm{a}, \mathrm{b}$ and $\mathrm{c})$ of parabola for various values of the shearing speed were presented in table 2. Coefficients of determination of the presented equations are within 0.584 to 0.780 but correlations at fourteen freedom degrees in three cases are significant for $\alpha=0.001$ and only in case of the lowest speed $\left(1 \mathrm{~m} \cdot \mathrm{s}^{-1}\right)-$ for $\alpha=0.02$.

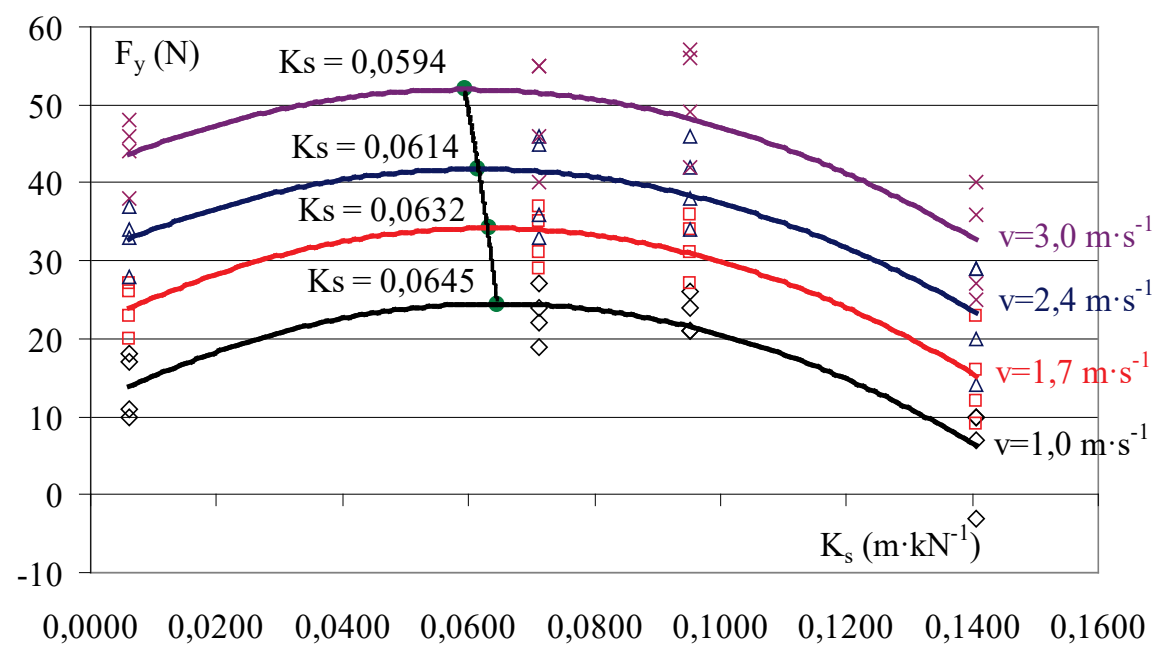

Figure 4. Impact of tine flexibility $\left(K_{s}\right)$ on vertical force value $\left(F_{y}\right)$ at various shearing speeds ( $v)$. 
Vertical forces acting...

A non-monotonic nature of the course with the maximum occurring therein may be explained with occurrence of two phenomena which accompany the increase of the tine flexibility, namely change in the vibrations frequency and the rake angle increase. According to some authors (Fenyvesi and Hudoba, 2010), flexibility of the shearing element influences the own vibrations frequency, which, as a result, causes decrease of the shearing resistance value, but only to the specific value of frequency. This information shows explicitly that the tine flexibility directly influences the vertical forces, but according to Al-Kheer et al., (2011) and Lisowski et al., (2016) those forces are correlated with the shearing resistance. The reduction of the vertical force value reported in the further part may be explained with the growing intensity of the increase of the rake angle of the cultivator point which accompanies the increase of the tine flexibility.

Table 2

Coefficients $(a, b, c)$ of the equation $F_{y}=a \cdot K_{s}^{2}+b \cdot K_{s}+c$, results of the statistical analysis and function extrema

\begin{tabular}{|c|c|c|c|c|c|c|c|c|}
\hline \multirow{2}{*}{$\begin{array}{l}\mathrm{v} \\
\left(\mathrm{m} \cdot \mathrm{s}^{-1}\right)\end{array}$} & \multicolumn{3}{|c|}{ Coefficients } & \multirow{2}{*}{$\mathrm{R}$} & \multirow{2}{*}{$\mathrm{p}$} & \multirow{2}{*}{ df } & \multirow{2}{*}{$\begin{array}{l}-\mathrm{b} \cdot(2 \cdot \mathrm{a})^{-1} \\
\left(\mathrm{~m} \cdot \mathrm{kN}^{-1}\right)\end{array}$} & \multirow{2}{*}{$\begin{array}{c}\mathrm{F}_{\mathrm{y}} \max \\
(\mathrm{N})\end{array}$} \\
\hline & a & $\mathrm{b}$ & $\mathrm{c}$ & & & & & \\
\hline 1.0 & 4-3128.9 & 403.49 & 11.467 & 0.764 & $<0,020$ & 14 & 0.06448 & 24 \\
\hline 1.7 & -3158.7 & 399.33 & 21.546 & 0.798 & $<0,001$ & 14 & 0.06321 & 34 \\
\hline 2.4 & -2925.3 & 359.11 & 30.714 & 0.883 & $<0,001$ & 14 & 0.06138 & 42 \\
\hline 3.0 & -2922.5 & 347.02 & 41.636 & 0.878 & $<0,001$ & 14 & 0.05937 & 52 \\
\hline
\end{tabular}

The mathematical analysis of equations, the coefficients of which were placed in table 2 , shows that the tine flexibility values $(-\mathrm{b} / 2 \mathrm{a})$, that correspond to the maximum vertical forces $\left(\mathrm{F}_{\mathrm{y}} \max \right)$ grow at the decrease of the shearing speed. Changes of the maximum vertical forces for corresponding flexibilities at particular shearing speeds were denoted in figure 4 with an additional line. As it may be observed (Figure 5) flexibility values at which the maximum vertical forces occur are significantly correlated with the shearing speed. This relation was described with the parabola equation for which determination coefficient is 0.0081. It suggests that for specific shearing speeds, optimal values of tines flexibility exist at which the tool will have better vertical stability and penetration ability. It means that at higher speeds of the treatment, tines with higher stiffness should be used.

Referring to the previously presented discussions concerning the impact of tines flexibility on the frequency of their vibrations, it may be assumed that between the shearing speed and flexibility there are interactions which result in the observed courses of vertical forces. This assumption requires, however, confirmation in experimental research. 
K. Lejman, Z. Owsiak, K. Pieczarka, T. Sekutowski

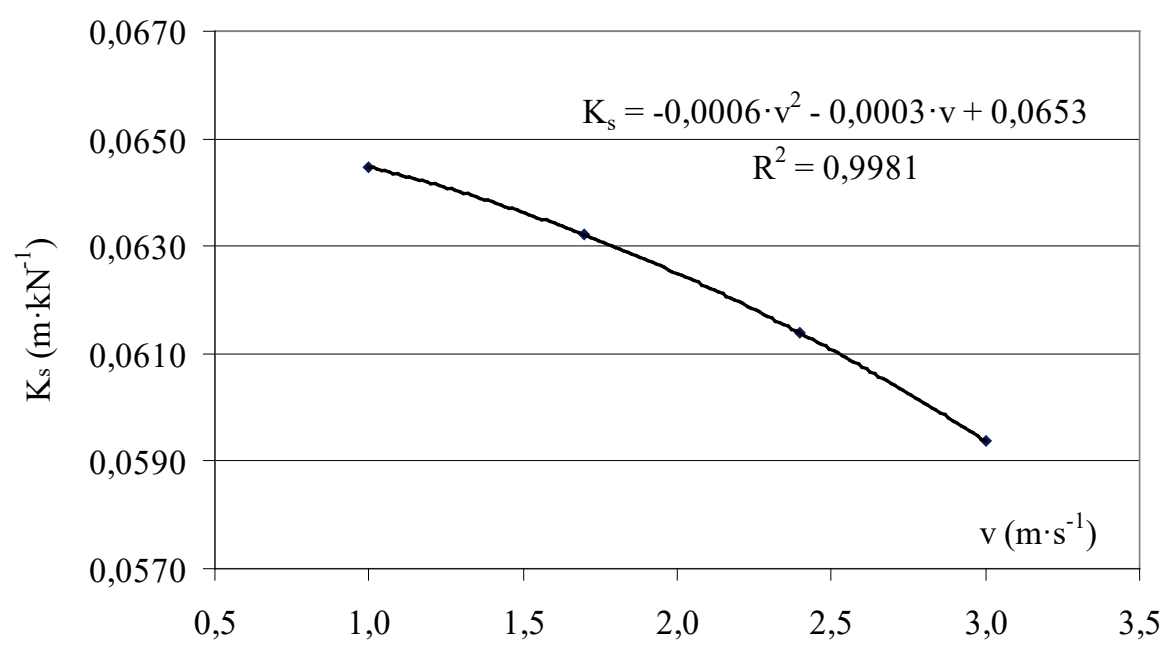

Figure 5. Impact of shearing speed (v) on tines flexibility $\left(K_{s}\right)$ corresponding to the maximum values of vertical forces

\section{Conclusions}

1. The increase of the shearing speed causes a statistically significant linear increase of the vertical force regardless the tine flexibility.

2. The intensity of the increase of the vertical force which is observed at the increase of the shearing speed does not significantly depend on the tine flexibility.

3. The increase of the value of tine flexibility initially causes increase and then decrease of the vertical force and penetration force value regardless the shearing speed, which was described with the second degree parabola equation.

4. Values of tines flexibility at which the highest vertical force value is observed parabolically decrease along with the increase of the shearing speed.

\section{References}

Al-Janobi, A.A.; Wahby, M.F.; Aboukarima, A.M.; Al-Hamed, S.A. (2002). Influence of chisel plow shank shape on horizontal and vertical force requirements. Agricultural Sciences, 7(1), 13-19.

Al-Kheer, A.A.; Kharmanda, M.G.; El Hami, A.; Mouazen, A.M. (2011). Estimating the variability of tillage forces on a chisel plough shank by modeling the variability of tillage system parameters. Computers and Electronics in Agriculture, 78, 61-70.

Askari, M.; Shahgholi, G.; Abbaspour-Gilandeh, Y.; Tash-Shamsabadi, H. (2016). The effect of new wings on subsoiler performance. Applied Engineering in Agriculture, 32(3), 353-362.

Berntsen, R.; Berre, B.; Torp, T.; Aasen, H. (2006). Tine forces established by a two-level model and the draught requirement of rigid and flexible tines. Soil \& Tillage Research, 90, 230-241.

Chen, Y.; Cavers, C.; Tessier, S.; Monero, F.; Lobb, D. (2005). Short-term tillage effects on soil cone index and plant development in a poorly drained, heavy clay soil. Soil \& Tillage Research, 82, $161-171$. 
Vertical forces acting...

Davoudi, S.; Alimardani, R.; Keyhani, A.; Atarnejad, R. (2008). A Two Dimensional Finite Element Analysis of a Plane Tillage Tool in Soil Using a Non-linear Elasto-Plastic Model. AmericanEurasian Journal of Agricultural \& Environmental Sciences, 3(3), 498-505.

Fenyvesi, L.; Hudoba, Z. (2010). Vibrating Tillage Tools. Soil Engineering. Springer, Berlin Heidelberg, 31-49.

Lejman, K.; Owsiak, Z.; Pieczarka, K.; Molendowski, F. (2015). Methodological aspects of determination of resultant force acting on the cultivator spring tines. Agricultural Engineering, 4(156), 69-78.

Lisowski, A.; Klonowski, J.; Green, O.; Świętochowski, A.; Sypuła, M.; Strużyk, A.; Nowakowski, T.; Chlebowski, J.; Kamiński, J.; Kostyra, K.; Mieszkalski, L.; Lauryna, D.; Margielski, J. (2016) Duckfoot tools connected with flexible and stiff tines: Three components of resistances and soil disturbance. Soil \& Tillage Research, 158, 76-90.

Manuwa, S.I. (2009). Performance evaluation of tillage tines operating under different depths in a sandy clay loam soil. Soil \& Tillage Research, 103, 399-405.

Przybył, J.; Kowalik, I.; Dach, J.; Zbytek, Z. (2009). Analiza jakości pracy agregatów do uprawy przedsiewnej. Journal of Research and Application in Agriculture Engineering, 4(54), 62-68.

Rouw, A.; Huon, S.; Soulileuth, B.; Jouquet, P.; Pierret, A.; Ribolzi, O.; Valentin, C; Bourdon, E.; Chantharath, B. (2010). Possibilities of carbon and nitrogen sequestration under conventional tillage and no-till cover crop farming (Mekong valley, Laos). Agriculture, Ecosystems and Environment, 136, 148-161.

Sahu, R.K.; Raheman, H. (2006). An approach for draft prediction of combination tillage implements in sandy clay loam soil. Soil \& Tillage Research, 90, 145-155.

Sánchez-Girón, V.; Ramırez, J.J.; Litago, J.J.; Hernanz, J.L. (2005). Effect of soil compaction and water content on the resulting forces acting on three seed drill furrow openers. Soil \& Tillage Research, 81, 25-37.

Shmulevich, I.; Asaf, Z.; Rubinstein, D. (2007). Interaction between soil and a wide cutting blade using the discrete element method. Soil \& Tillage Research, 97, 37-50.

Talarczyk, W.; Zbytek, Z. (2006). Wpływ głębokości roboczej agregatu do bezorkowej uprawy gleby na obciążenia eksploatacyjne. Inżynieria Rolnicza, 4(79), 303-312.

Ucgul, M.; Fielke, J.M.; Saunders, C. (2015). Defining the effect of sweep tillage tool cutting edge geometry on tillage forces using 3D discrete element modeling. Information Processing in Agriculture, 2, 130-141

Wahed, A.; Aboukarima, M. (2007). Draft models of chisel plow based on simulation using artificial neural networks. Misr Journal of Agricultural Engineering, 24(1), 42-61.

Zhang, X.; Chen,Y. (2017). Soil disturbance and cutting forces of four different sweeps for mechanical weeding. Soil \& Tillage Research, 168, 167-175. 
K. Lejman, Z. Owsiak, K. Pieczarka, T. Sekutowski

\title{
SILY PIONOWE DZIAŁAJĄCE NA ZĘBY KULTYWATORA W ASPEKCIE ZMIAN PRĘDKOŚCI SKRAWANIA I SPRĘŻYSTOŚCI ZĘBÓW
}

\begin{abstract}
Streszczenie. Celem pracy było wyznaczenie wpływu prędkości skrawania i sprężystości zębów kultywatora na wartości sił pionowych. Badania przeprowadzono w warunkach polowych w glebie o uziarnieniu gliny piaszczystej i średniej wilgotności $11,2 \%$. Mierzono siły pionowe działające na zmodyfikowane cztery esowe zęby o sprężystościach 0,$0061 ; 0,0711 ; 0,0953 \mathrm{i} 0,1406 \mathrm{~m} \cdot \mathrm{kN}^{-1}$. Zęby zakończone były redliczką o promieniu krzywizny $0,17 \mathrm{~m}$. Pomiary wykonywano dla czterech prędkości skrawania $\left(1,0 ; 1,7 ; 2,4\right.$ i $\left.3,0 \mathrm{~m} \cdot \mathrm{s}^{-1}\right)$ i przy głębokości skrawania $11 \mathrm{~cm}$. Stosowano stanowisko do pomiarów sił działających na narzędzia rolnicze skrawające glebę w warunkach polowych. Stwierdzono, że wzrost prędkości skrawania powoduje liniowy przyrost siły pionowej zagłębiającej, przy czym gradient przyrostu nie zależy od sprężystości zębów. Stwierdzono również, że wzrost sprężystości powoduje początkowo wzrost, a następnie spadek siły pionowej, co opisano równaniem paraboli stopnia drugiego. Sprężystości, przy których występują ekstrema przebiegów, rosną wraz ze spadkiem prędkości skrawania.
\end{abstract}

Słowa kluczowe: gleba, kultywator, ząb sprężynowy, siły pionowe, prędkość skrawania 